\title{
Analysis on thermodynamic performance of ancient pagodas considering flow heat transfer properties
}

\author{
Wei Liu*, Sheliang Wang, Tao Yang, Yuan Zhou \\ Xi'an University of Architecture and Technology, Xi'an 710055, China \\ Corresponding Author Email: liuweijyy@163.com
}

https://doi.org/10.18280/ijht.360416

Received: 21 March 2018

Accepted: 14 July 2018

\section{Keywords:}

ancient pagodas, thermodynamic performance, heat transfer properties, reflux effect, drifting

\begin{abstract}
The optimization of cooling and ventilation systems is essential to the protection of ancient pagodas, which boast profound historical, cultural and tourism values. This calls for thorough investigation into the thermodynamic and flow heat transfer properties of the central airconditioning system (CACS) in the pagoda. In this paper, a thermodynamic model of the cooling tower is established in the principle of differential calculation, and verified through field test. On this basis, the author further discussed the impacts of drifting and reflux effect on the working performance of the cooling tower. The results show that: without considering the drifting effect, there is only a slight error between the measured inlet air enthalpy, inlet air temperature and inlet air relative humidity and the values simulated by the proposed model; in actual operation, the drifting of water vapour away from the cooling tower carries away some heat, leading to reduced temperature and increased relative humidity at the air inlet; the reflux ratio within the cooling tower is positively correlated with the water temperature, dry-bulb temperature and relative humidity at the outlet of the cooling tower, but negatively with the heat exchange amount of the tower, under different atmospheric dry-bulb temperatures, atmospheric relative humidities and gas-water ratios; the reflux of water vapour has a significant impact on the cooling performance of the cooling tower, and the impact is positively correlated to the reflux ratio. The research findings provide theoretical support for engineering applications like heating, cooling and ventilation in ancient pagodas.
\end{abstract}

\section{INTRODUCTION}

There are numerous ancient pagodas around the world, especially in Asia. These towers fall into attic style, multi-eave style, pavilion-style or Vajra base-style [1-2]. Ancient pagodas are an important cultural heritage of all mankind, carrying profound historical, cultural and tourism values [3].

It is a money-consuming task to preserve the original physical structure of ancient pagodas, owing to their long history [4-8]. Heating, cooling and ventilation should also be considered for some ancient pagodas, which are open to the public as historical and cultural landscapes [9].

For the protection of ancient pagodas, the cooling tower, the key component to the working efficiency of central airconditioning system (CACS), is generally placed in a ground pit [10-11]. In this case, the reflux effect may occur in the cooling tower under the crosswind. This effect must be considered in the thermodynamic simulation and theoretical calculation of the cooling tower [12-16].

Much research has been done on the thermodynamic properties and flow heat transfer of the cooling tower. For instance, Fisenko et al. improved the thermodynamic model of conventional cooling towers using the Merkel theory, and included such parameters as the reflux of hot and humid air and the air enthalpy into the proposed model [17]. Inspired by the effectiveness-number of transfer units ( $\varepsilon-\mathrm{NTU})$ method, Söylemez et al. provided a theoretical reference to the selection and design of the cooling tower [18]. Johannes et al. considered the impact of the Lewis coefficient on the performance of the cooling tower, and determine the Lewis coefficient corresponding to the optimal cooling tower outlet temperature by theoretical modelling [19]. Kie et al. designed an intelligent control system to reduce the energy consumption of the cooling tower, and discussed how the heat transfer features of air and water affect the thermodynamic performance of the cooling tower [20]. Gao et al. numerically simulated the effect of ambient crosswind on the thermodynamic performance of the cooling tower [21]. In addition, other scholars mainly analysed the influence of various thermodynamic parameters (e.g. outlet water temperature, gas temperature, ventilation rate and ventilation resistance) over the overall design and heat transfer properties of the cooling tower [22-24]. However, there is a huge deviation of the simulated results from the actual results in the above studies, which fail to consider the gas reflux, drifting, ambient temperature, ambient humidity, etc. [25].

To overcome the said defects, this paper probes into the thermodynamic performance and heat transfer properties of the CACS in ancient pagodas, establishes a thermodynamic model of the cooling tower in the principle of differential calculation, and verifies the rationality of the proposed model through field test. On this basis, the author further discussed the impacts of drifting and reflux effect on the working performance of the cooling tower. The research findings provide theoretical support for engineering applications like heating, cooling and ventilation in ancient pagodas. 


\section{THERMODYNAMIC MODEL AND HEAT TRANSFER FEATURES OF COOLING TOWER}

Based on the Lewis theory, the heat transfer relationship in the cooling tower can be expressed as:

$$
\frac{\alpha}{\sigma}=c_{p}
$$

where $\alpha$ and $\sigma$ are respectively the sensible heat transfer coefficient and the wet exchange coefficient; $c_{p}$ is the constant pressure heat capacity. Equation 1 describes the ideal heat exchange process. In actual work, the heat transfer relationship in the cooling tower should be corrected by:

$$
L_{e}=\frac{\alpha}{\sigma c_{p}}
$$

The number of cooling tower properties $\mathrm{N}$ can be expressed as:

$$
N=\frac{\beta V}{G_{w}}=A \lambda^{m}
$$

where $\mathrm{N}$ is the cooling capacity of the cooling tower; $\beta, \mathrm{A}$ and $\mathrm{m}$ are the volume and packing coefficient of the cooling tower, respectively; $\lambda$ is the gas-water ratio.

The outlet water temperature and outlet air parameters were calculated by the method shown in Figure 1.

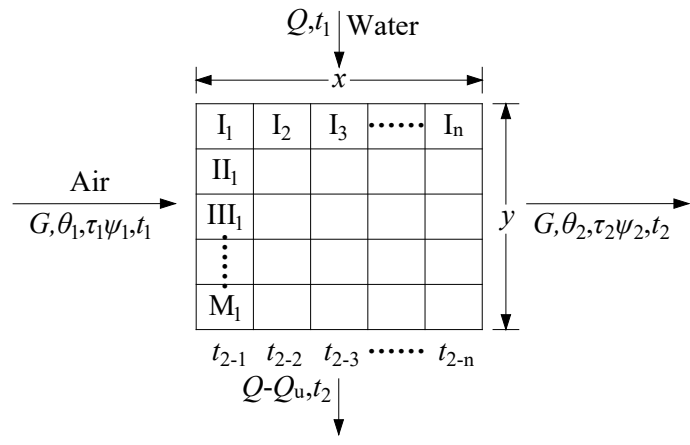

Figure 1. Difference calculation of cooling tower parameters

Here, a certain plane is divided into $\mathrm{n} \square \mathrm{M}$ units. The cells in the first column are denoted as I1, II 1, .., M1, and those in the second column are denoted as I1, I2, .., In. The state parameters of the air are already known. During the numerical calculation, the outlet water temperature and outlet air parameters were computed cell to cell from left to right and from top to bottom.

In actual operation, the water vapour that has been discharged may re-enter the cooling water with the inlet air, creating the reflux phenomenon. The reflux ratio $r$ can be calculated as follows:

$r_{e}=\frac{h_{1}-h_{\mathrm{aa}}}{h_{2}-h_{\mathrm{aa}}}$

where $h_{1}, h_{2}$ and $h_{\text {aa }}$ are the enthalpies of inlet air, outlet air and the ambient atmosphere, respectively. The three enthalpies obey the following relationship: $\frac{h_{1}-h_{\text {aа }}}{d_{1}-d_{\text {aа }}}=\frac{h_{2}-h_{\text {aа }}}{d_{2}-d_{\text {aа }}}$

where $d_{1}, d_{2}$ and $d_{\mathrm{aa}}$ are the water vapour contents of inlet air, outlet air and the ambient atmosphere, respectively. According to the heat balance equation, we have:

$\frac{\left(t_{2}-t_{1}\right)}{\left(d_{2}-d_{1}\right)}=L_{e} \frac{t_{\mathrm{w}}-t_{\mathrm{a}}}{d_{\mathrm{w}}-d_{\mathrm{a}}}$

where $t_{1}, t_{2}$ and $t_{\text {aa }}$ are the dry-bulb temperatures of inlet air, outlet air and the ambient atmosphere, respectively. Hence, the cooling number $\mathrm{d} \Omega$ in each cell of Figure 1 can be expressed as:

$\mathrm{d} \Omega=\frac{c_{\mathrm{w}} \mathrm{d} t}{h_{\mathrm{w}}-h_{\mathrm{a}}}$

The thermodynamic calculation model of the cooling tower can be established below according to equations (1)-(7).

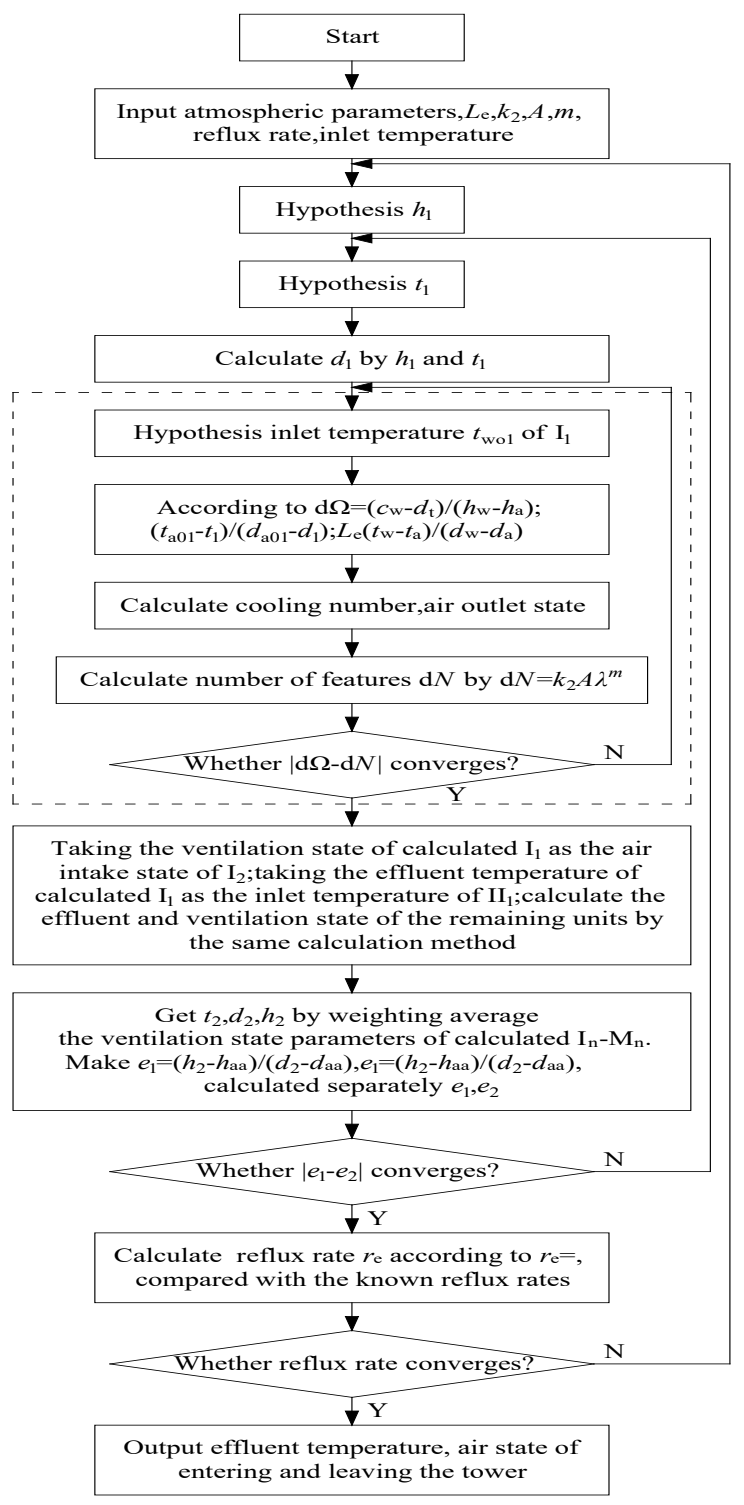

Figure 2. The thermodynamic calculation model of the cooling tower 


\section{THERMODYNAMIC MODEL VERIFICATION AND ANALYSIS}

Taking the CACS of a certain ancient pagoda for instance, the author tested the inlet air enthalpy, inlet air temperature, inlet air humidity, outlet water temperature and heat exchange capacity of the cooling tower. The test devices were arranged at the corresponding positions of the cooling tower, and the results were transmitted by sensors to the data processing system through for post-analysis. The test process is shown in Figure 3 below.

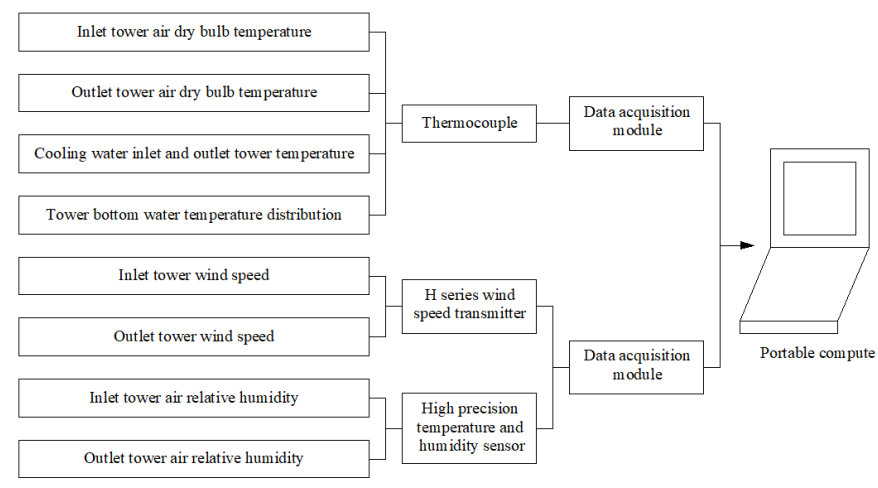

Figure 3. Testing of thermodynamic parameters of the cooling tower

Seven typical test results, denoted as T1 T7, were selected for analysis. The measured results were contrasted against those computed by the proposed method. Figure 4 compares the theoretical results and test results on the inlet air enthalpy, inlet air temperature and inlet air relative humidity of the cooling tower.

It can be seen from Figure 4 that the relative error between the calculated and measured inlet air enthalpies of the cooling tower was merely $3 \%$, that between the calculated and measured inlet air temperatures was relatively large (14\%), and that between the calculated and measured inlet air relative humidity peaked at $25.8 \%$.

The calculated temperature and relative humidity of the inlet air were corrected against the psychrometric chart (Figure 5), where points 1, 2 and 3 respectively stand for the ambient atmosphere state, inlet air state and outlet air state of the cooling tower, and point 4 , i.e. the intersection between line $2 \sim 1$ and line $2 \sim 3$, refers to the state point calculated by the proposed theoretical model.

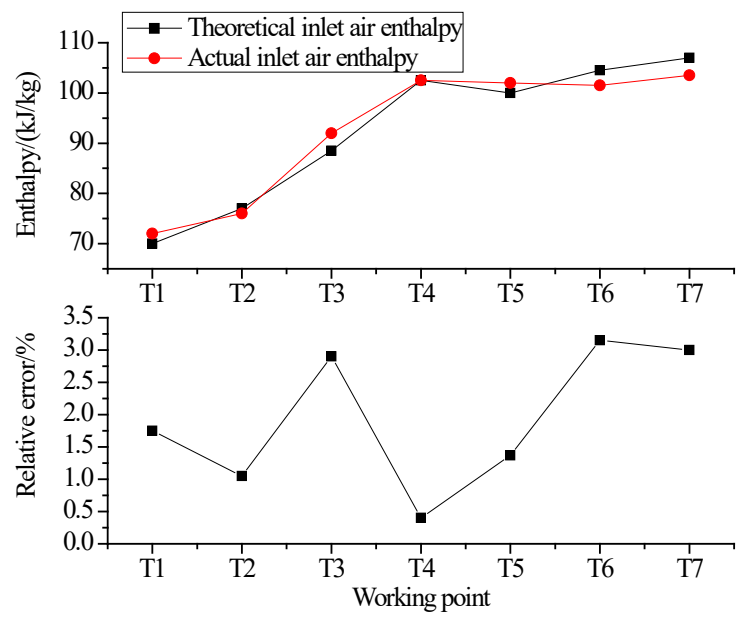

(a) Inlet air enthalpy
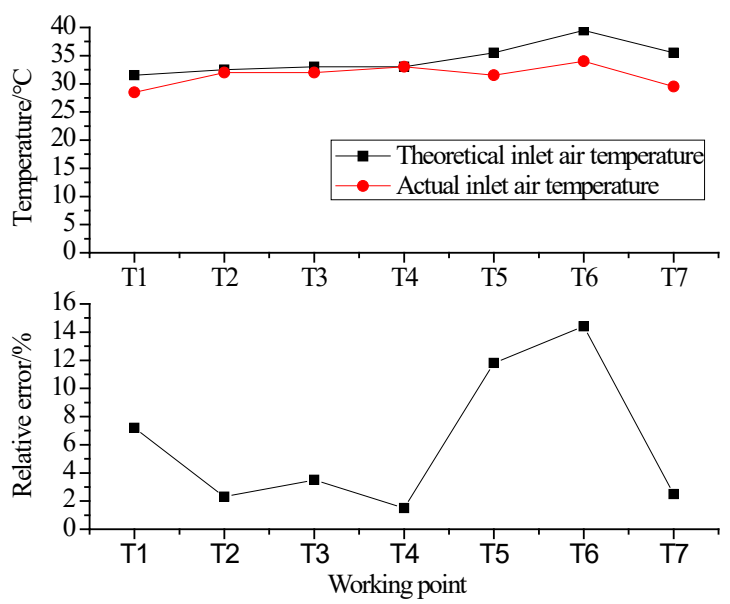

(b) Inlet air temperature

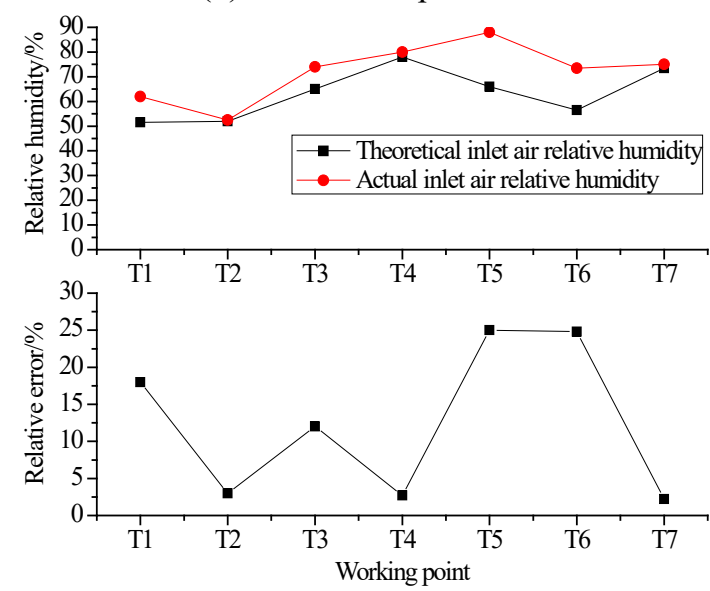

(c) Inlet air relative humidity

Figure 4. Comparison between the theoretical results and test results on the inlet air enthalpy, inlet air temperature and inlet air relative humidity of the cooling tower

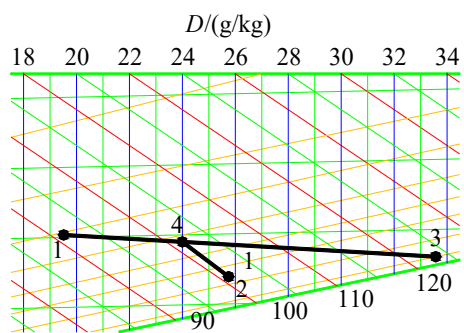

Figure 5. The psychrometric chart of cooling tower state parameters

When raw materials are fed into the cooling tower, a part of the cooling water will drift away from the air inlet, carrying away some heat. As a result, the temperature at the air inlet is lowered and the relative humidity at this position is increased. However, the proposed theoretical model fails to consider the drifting effect of cooling water.

Taking point 4 as the benchmark, the results calculated by the proposed model were compared with the test results. The statistics on inlet air temperature and its relative humidity are displayed as Figure 6.

Comparing the calculated and tested inlet air temperature and inlet air relative humidity of the cooling tower without considering the drifting effect, it is learned that the maximum error of inlet air temperature was only $2.7 \%$ and that of the 
relative humidity was merely $3.3 \%$. Hence, the proposed model was proved feasible using the psychrometric chart.

Next, the author discussed the impacts of water vapour reflux on the efficiency of the cooling tower. Table 1 simulates the impacts of water vapour reflux ratio on outlet water temperature, heat exchange amount between the inside and the outside, the dry-bulb temperature of outlet air and the relative humidity of the outlet air of the cooling tower, as the atmospheric dry-bulb temperature increased from $24^{\circ} \mathrm{C}$ to $36^{\circ} \mathrm{C}$.
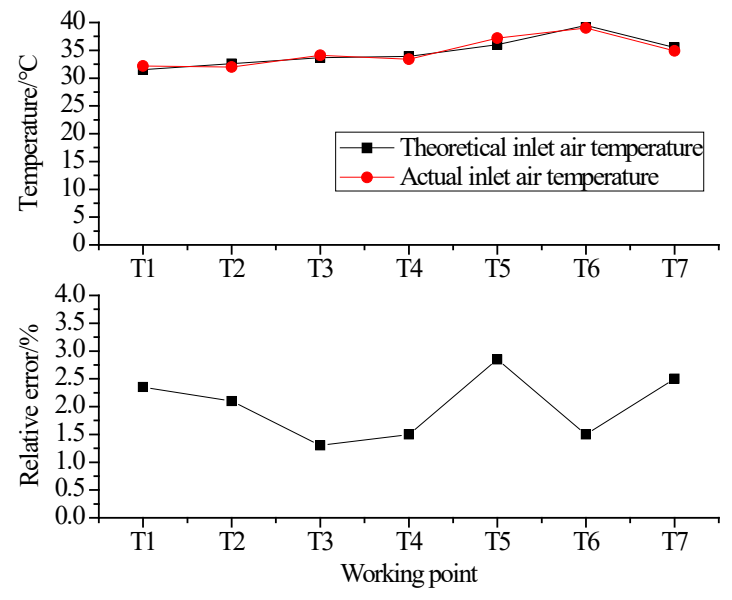

(a) Inlet air temperature

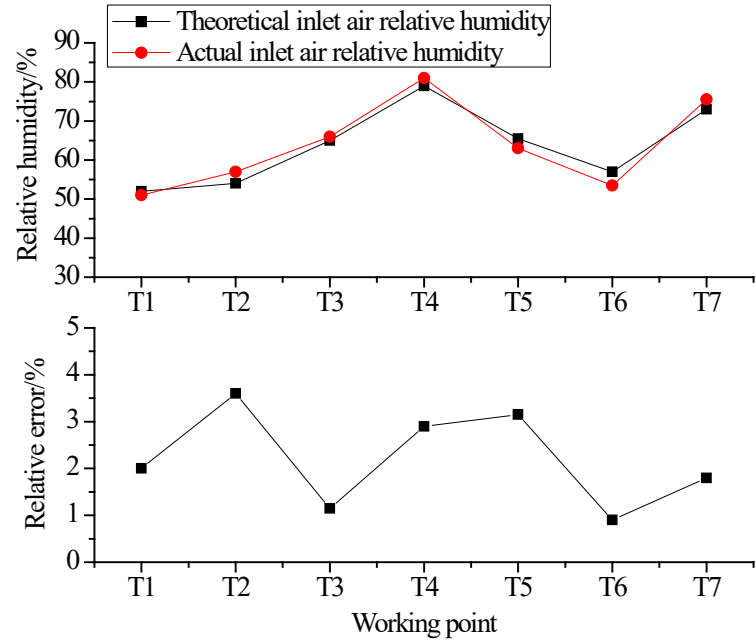

(b) Inlet air relative humidity

Figure 6. Comparison between the calculated and tested inlet air temperature and inlet air relative humidity of the cooling tower without considering the drifting effect

Table 1. The impacts of water vapour reflux ratio on outlet water temperature, heat exchange amount, dry-bulb temperature of outlet air and relative humidity of the outlet air under different atmospheric dry-bulb temperatures

\begin{tabular}{|c|c|c|c|c|c|c|c|c|c|c|}
\hline & \multicolumn{9}{|c|}{ Reflux ratio/\% } \\
\hline & & 0 & 10 & 20 & 30 & 40 & 50 & 60 & 70 & 80 \\
\hline \multirow{7}{*}{ Outlet water temperature $/{ }^{\circ} \mathrm{C}$} & $t_{\mathrm{a}}=24^{\circ} \mathrm{C}$ & 28.40 & 28.85 & 29.30 & 29.75 & 30.20 & 30.65 & 31.10 & 31.55 & 32.00 \\
\hline & $t_{\mathrm{a}}=26^{\circ} \mathrm{C}$ & 29.00 & 29.39 & 29.78 & 30.16 & 30.55 & 30.94 & 31.33 & 31.71 & 32.10 \\
\hline & $t_{\mathrm{a}}=28^{\circ} \mathrm{C}$ & 29.60 & 29.93 & 30.25 & 30.58 & 30.90 & 31.23 & 31.55 & 31.88 & 32.20 \\
\hline & $t_{\mathrm{a}}=30^{\circ} \mathrm{C}$ & 30.20 & 30.46 & 30.73 & 30.99 & 31.25 & 31.51 & 31.78 & 32.04 & 32.30 \\
\hline & $t_{\mathrm{a}}=32^{\circ} \mathrm{C}$ & 30.80 & 31.00 & 31.20 & 31.40 & 31.60 & 31.80 & 32.00 & 32.20 & 32.40 \\
\hline & $t_{\mathrm{a}}=34^{\circ} \mathrm{C}$ & 31.40 & 31.54 & 31.68 & 31.81 & 31.95 & 32.09 & 32.23 & 32.36 & 32.50 \\
\hline & $t_{\mathrm{a}}=36^{\circ} \mathrm{C}$ & 32.00 & 32.08 & 32.15 & 32.23 & 32.30 & 32.38 & 32.45 & 32.53 & 32.60 \\
\hline \multirow{6}{*}{ Heat/MW } & $t_{\mathrm{a}}=24^{\circ} \mathrm{C}$ & 1.83 & 1.71 & 1.59 & 1.47 & 1.36 & 1.24 & 1.12 & 1.00 & 0.88 \\
\hline & $t_{\mathrm{a}}=26^{\circ} \mathrm{C}$ & 1.70 & 1.59 & 1.49 & 1.38 & 1.28 & 1.17 & 1.06 & 0.96 & 0.85 \\
\hline & $t_{\mathrm{a}}=28^{\circ} \mathrm{C}$ & 1.56 & 1.47 & 1.38 & 1.29 & 1.20 & 1.10 & 1.01 & 0.92 & 0.83 \\
\hline & $t_{\mathrm{a}}=30^{\circ} \mathrm{C}$ & 1.43 & 1.35 & 1.27 & 1.19 & 1.12 & 1.04 & 0.96 & 0.88 & 0.80 \\
\hline & $t_{\mathrm{a}}=32^{\circ} \mathrm{C}$ & 1.29 & 1.23 & 1.16 & 1.10 & 1.04 & 0.97 & 0.91 & 0.84 & 0.78 \\
\hline & $t_{\mathrm{a}}=34^{\circ} \mathrm{C}$ & 1.16 & 1.11 & 1.06 & 1.01 & 0.96 & 0.90 & 0.85 & 0.80 & 0.75 \\
\hline \multirow{7}{*}{ Outlet air relative humidity $/{ }^{\circ} \mathrm{C}$} & $t_{\mathrm{a}}=24^{\circ} \mathrm{C}$ & 29.40 & 29.78 & 30.15 & 30.53 & 30.90 & 31.28 & 31.65 & 32.03 & 32.40 \\
\hline & $t_{\mathrm{a}}=26^{\circ} \mathrm{C}$ & 30.28 & 30.60 & 30.91 & 31.23 & 31.54 & 31.86 & 32.17 & 32.49 & 32.80 \\
\hline & $t_{\mathrm{a}}=28^{\circ} \mathrm{C}$ & 31.17 & 31.42 & 31.68 & 31.93 & 32.18 & 32.44 & 32.69 & 32.95 & 33.20 \\
\hline & $t_{\mathrm{a}}=30^{\circ} \mathrm{C}$ & 32.05 & 32.24 & 32.44 & 32.63 & 32.83 & 33.02 & 33.21 & 33.41 & 33.60 \\
\hline & $t_{\mathrm{a}}=32^{\circ} \mathrm{C}$ & 32.93 & 33.07 & 33.20 & 33.33 & 33.47 & 33.60 & 33.73 & 33.87 & 34.00 \\
\hline & $t_{\mathrm{a}}=34^{\circ} \mathrm{C}$ & 33.82 & 33.89 & 33.96 & 34.04 & 34.11 & 34.18 & 34.25 & 34.33 & 34.40 \\
\hline & $t_{\mathrm{a}}=36^{\circ} \mathrm{C}$ & 34.70 & 34.71 & 34.73 & 34.74 & 34.75 & 34.76 & 34.78 & 34.79 & 34.80 \\
\hline \multirow{7}{*}{ Outlet air relative humidity $/{ }^{\circ} \mathrm{C}$} & $t_{\mathrm{a}}=24^{\circ} \mathrm{C}$ & 100.00 & 100.00 & 100.00 & 100.00 & 100.00 & 100.00 & 100.00 & 100.00 & 100.00 \\
\hline & $t_{\mathrm{a}}=26^{\circ} \mathrm{C}$ & 100.00 & 100.00 & 100.00 & 100.00 & 100.00 & 100.00 & 100.00 & 100.00 & 100.00 \\
\hline & $t_{\mathrm{a}}=28^{\circ} \mathrm{C}$ & 97.50 & 97.92 & 98.33 & 98.75 & 99.17 & 99.58 & 100.00 & 100.00 & 100.00 \\
\hline & $t_{\mathrm{a}}=30^{\circ} \mathrm{C}$ & 95.33 & 95.71 & 96.09 & 96.48 & 96.86 & 97.25 & 97.63 & 98.02 & 98.40 \\
\hline & $t_{\mathrm{a}}=32^{\circ} \mathrm{C}$ & 93.15 & 93.69 & 94.24 & 94.78 & 95.33 & 95.87 & 96.41 & 96.96 & 97.50 \\
\hline & $t_{\mathrm{a}}=34^{\circ} \mathrm{C}$ & 90.98 & 91.49 & 92.01 & 92.52 & 93.04 & 93.55 & 94.07 & 94.58 & 95.10 \\
\hline & $t_{\mathrm{a}}=36^{\circ} \mathrm{C}$ & 88.80 & 89.28 & 89.75 & 90.23 & 90.70 & 91.18 & 91.65 & 92.13 & 92.60 \\
\hline
\end{tabular}

Table 2 simulates the impacts of water vapour reflux ratio on outlet water temperature, heat exchange amount between the inside and the outside, the dry-bulb temperature of outlet air and the relative humidity of the outlet air of the cooling tower, as the atmospheric relative humidity increased from $30 \%$ to $90 \%$.

Table 2. The impacts of water vapour reflux ratio on outlet water temperature, heat exchange amount, dry-bulb temperature of outlet air and relative humidity of the outlet air under different atmospheric relative humidities 


\begin{tabular}{|c|c|c|c|c|c|c|c|c|c|c|}
\hline & & \multicolumn{9}{|c|}{ Reflux ratio/\% } \\
\hline & & 0 & 10 & 20 & 30 & 40 & 50 & 60 & 70 & 80 \\
\hline \multirow{7}{*}{ Outlet water temperature $/{ }^{\circ} \mathrm{C}$} & $\mathrm{RH}=30 \%$ & 29.40 & 29.90 & 30.40 & 30.90 & 31.40 & 31.90 & 32.40 & 32.90 & 33.40 \\
\hline & $\mathrm{RH}=40 \%$ & 30.28 & 30.70 & 31.12 & 31.53 & 31.95 & 32.37 & 32.78 & 33.20 & 33.62 \\
\hline & $\mathrm{RH}=50 \%$ & 31.17 & 31.50 & 31.83 & 32.17 & 32.50 & 32.83 & 33.17 & 33.50 & 33.83 \\
\hline & $\mathrm{RH}=60 \%$ & 32.05 & 32.30 & 32.55 & 32.80 & 33.05 & 33.30 & 33.55 & 33.80 & 34.05 \\
\hline & $\mathrm{RH}=70 \%$ & 32.93 & 33.10 & 33.27 & 33.43 & 33.60 & 33.77 & 33.93 & 34.10 & 34.27 \\
\hline & $\mathrm{RH}=80 \%$ & 33.82 & 33.90 & 33.98 & 34.07 & 34.15 & 34.23 & 34.32 & 34.40 & 34.48 \\
\hline & $\mathrm{RH}=90 \%$ & 34.70 & 34.70 & 34.70 & 34.70 & 34.70 & 34.70 & 34.70 & 34.70 & 34.70 \\
\hline \multirow{7}{*}{ Heat/MW } & $\mathrm{RH}=30 \%$ & 1.60 & 1.47 & 1.34 & 1.21 & 1.08 & 0.94 & 0.81 & 0.68 & 0.55 \\
\hline & $\mathrm{RH}=40 \%$ & 1.39 & 1.28 & 1.17 & 1.07 & 0.96 & 0.85 & 0.74 & 0.63 & 0.52 \\
\hline & $\mathrm{RH}=50 \%$ & 1.19 & 1.10 & 1.01 & 0.92 & 0.84 & 0.75 & 0.66 & 0.57 & 0.49 \\
\hline & $\mathrm{RH}=60 \%$ & 0.98 & 0.91 & 0.85 & 0.78 & 0.72 & 0.65 & 0.59 & 0.52 & 0.46 \\
\hline & $\mathrm{RH}=70 \%$ & 0.77 & 0.73 & 0.69 & 0.64 & 0.60 & 0.55 & 0.51 & 0.47 & 0.42 \\
\hline & $\mathrm{RH}=80 \%$ & 0.57 & 0.54 & 0.52 & 0.50 & 0.48 & 0.46 & 0.44 & 0.41 & 0.39 \\
\hline & $\mathrm{RH}=90 \%$ & 0.36 & 0.36 & 0.36 & 0.36 & 0.36 & 0.36 & 0.36 & 0.36 & 0.36 \\
\hline \multirow{7}{*}{ Outlet air relative humidity $/{ }^{\circ} \mathrm{C}$} & $\mathrm{RH}=30 \%$ & 33.50 & 33.65 & 33.80 & 33.95 & 34.10 & 34.25 & 34.40 & 34.55 & 34.70 \\
\hline & $\mathrm{RH}=40 \%$ & 33.78 & 33.91 & 34.03 & 34.16 & 34.28 & 34.41 & 34.53 & 34.66 & 34.78 \\
\hline & $\mathrm{RH}=50 \%$ & 34.07 & 34.17 & 34.27 & 34.37 & 34.47 & 34.57 & 34.67 & 34.77 & 34.87 \\
\hline & $\mathrm{RH}=60 \%$ & 34.35 & 34.43 & 34.50 & 34.58 & 34.65 & 34.73 & 34.80 & 34.88 & 34.95 \\
\hline & $\mathrm{RH}=70 \%$ & 34.63 & 34.68 & 34.73 & 34.78 & 34.83 & 34.88 & 34.93 & 34.98 & 35.03 \\
\hline & $\mathrm{RH}=80 \%$ & 34.92 & 34.94 & 34.97 & 34.99 & 35.02 & 35.04 & 35.07 & 35.09 & 35.12 \\
\hline & $\mathrm{RH}=90 \%$ & 35.20 & 35.20 & 35.20 & 35.20 & 35.20 & 35.20 & 35.20 & 35.20 & 35.20 \\
\hline \multirow{7}{*}{ Outlet air relative humidity $/{ }^{\circ} \mathrm{C}$} & $\mathrm{RH}=30 \%$ & 83.80 & 85.26 & 86.73 & 88.19 & 89.65 & 91.11 & 92.58 & 94.04 & 95.50 \\
\hline & $\mathrm{RH}=40 \%$ & 86.20 & 87.42 & 88.64 & 89.86 & 91.08 & 92.29 & 93.51 & 94.73 & 95.95 \\
\hline & $\mathrm{RH}=50 \%$ & 88.60 & 89.58 & 90.55 & 91.53 & 92.50 & 93.48 & 94.45 & 95.43 & 96.40 \\
\hline & $\mathrm{RH}=60 \%$ & 91.00 & 91.73 & 92.46 & 93.19 & 93.93 & 94.66 & 95.39 & 96.12 & 96.85 \\
\hline & $\mathrm{RH}=70 \%$ & 93.40 & 93.89 & 94.38 & 94.86 & 95.35 & 95.84 & 96.33 & 96.81 & 97.30 \\
\hline & $\mathrm{RH}=80 \%$ & 95.80 & 96.04 & 96.29 & 96.53 & 96.78 & 97.02 & 97.26 & 97.51 & 97.75 \\
\hline & $\mathrm{RH}=90 \%$ & 98.20 & 98.20 & 98.20 & 98.20 & 98.20 & 98.20 & 98.20 & 98.20 & 98.20 \\
\hline
\end{tabular}

Table 3 simulates the impacts of water vapour reflux ratio on outlet water temperature, heat exchange amount between the inside and the outside, the dry-bulb temperature of outlet air and the relative humidity of the outlet air of the cooling tower, as the gas-water ratio increased from 0.3 to 1.2 .

Table 3. The impacts of water vapour reflux ratio on outlet water temperature, heat exchange amount, dry-bulb temperature of outlet air and relative humidity of the outlet air under different gas-water ratios

\begin{tabular}{|c|c|c|c|c|c|c|c|c|c|c|}
\hline & \multicolumn{9}{|c|}{ Reflux ratio/\% } \\
\hline & & 0 & 10 & 20 & 30 & 40 & 50 & 60 & 70 & 80 \\
\hline \multirow{6}{*}{ Outlet water temperature $/{ }^{\circ} \mathrm{C}$} & Gas-water ratio $=0.3$ & 33.40 & 33.54 & 33.68 & 33.81 & 33.95 & 34.09 & 34.23 & 34.36 & 34.50 \\
\hline & Gas-water ratio $=0.5$ & 32.30 & 32.50 & 32.70 & 32.90 & 33.10 & 33.30 & 33.50 & 33.70 & 33.90 \\
\hline & Gas-water ratio $=0.7$ & 31.50 & 31.76 & 32.01 & 32.27 & 32.53 & 32.78 & 33.04 & 33.29 & 33.55 \\
\hline & Gas-water ratio $=0.9$ & 30.90 & 31.18 & 31.46 & 31.74 & 32.03 & 32.31 & 32.59 & 32.87 & 33.15 \\
\hline & Gas-water ratio $=1.1$ & 30.30 & 30.63 & 30.95 & 31.28 & 31.60 & 31.93 & 32.25 & 32.58 & 32.90 \\
\hline & Gas-water ratio $=1.2$ & 30.10 & 30.44 & 30.78 & 31.11 & 31.45 & 31.79 & 32.13 & 32.46 & 32.80 \\
\hline \multirow{6}{*}{ Heat/MW } & Gas-water ratio $=0.3$ & 2.85 & 2.68 & 2.51 & 2.34 & 2.18 & 2.01 & 1.84 & 1.67 & 1.50 \\
\hline & Gas-water ratio $=0.5$ & 2.45 & 2.31 & 2.16 & 2.02 & 1.88 & 1.73 & 1.59 & 1.44 & 1.30 \\
\hline & Gas-water ratio $=0.7$ & 2.18 & 2.06 & 1.93 & 1.81 & 1.69 & 1.56 & 1.44 & 1.31 & 1.19 \\
\hline & Gas-water ratio $=0.9$ & 1.90 & 1.79 & 1.68 & 1.57 & 1.47 & 1.36 & 1.25 & 1.14 & 1.03 \\
\hline & Gas-water ratio $=1.1$ & 1.73 & 1.63 & 1.54 & 1.44 & 1.35 & 1.25 & 1.15 & 1.06 & 0.96 \\
\hline & Gas-water ratio $=1.2$ & 1.65 & 1.56 & 1.46 & 1.37 & 1.28 & 1.18 & 1.09 & 0.99 & 0.90 \\
\hline \multirow{6}{*}{ Outlet air relative humidity $/{ }^{\circ} \mathrm{C}$} & Gas-water ratio $=0.3$ & 34.95 & 34.99 & 35.04 & 35.08 & 35.13 & 35.17 & 35.21 & 35.26 & 35.30 \\
\hline & Gas-water ratio $=0.5$ & 34.49 & 34.55 & 34.62 & 34.68 & 34.75 & 34.81 & 34.87 & 34.94 & 35.00 \\
\hline & Gas-water ratio $=0.7$ & 34.18 & 34.26 & 34.34 & 34.41 & 34.49 & 34.57 & 34.65 & 34.72 & 34.80 \\
\hline & Gas-water ratio $=0.9$ & 33.92 & 34.01 & 34.09 & 34.18 & 34.26 & 34.35 & 34.43 & 34.52 & 34.60 \\
\hline & Gas-water ratio $=1.1$ & 33.75 & 33.84 & 33.92 & 34.01 & 34.09 & 34.18 & 34.26 & 34.35 & 34.43 \\
\hline & Gas-water ratio $=1.2$ & 33.67 & 33.76 & 33.84 & 33.93 & 34.01 & 34.10 & 34.18 & 34.27 & 34.35 \\
\hline \multirow{6}{*}{ Outlet air relative humidity $/{ }^{\circ} \mathrm{C}$} & Gas-water ratio $=0.3$ & 95.20 & 95.48 & 95.75 & 96.03 & 96.30 & 96.58 & 96.85 & 97.13 & 97.40 \\
\hline & Gas-water ratio $=0.5$ & 92.00 & 92.54 & 93.08 & 93.61 & 94.15 & 94.69 & 95.23 & 95.76 & 96.30 \\
\hline & Gas-water ratio $=0.7$ & 89.80 & 90.51 & 91.23 & 91.94 & 92.65 & 93.36 & 94.08 & 94.79 & 95.50 \\
\hline & Gas-water ratio $=0.9$ & 87.90 & 88.79 & 89.68 & 90.56 & 91.45 & 92.34 & 93.23 & 94.11 & 95.00 \\
\hline & Gas-water ratio $=1.1$ & 86.20 & 87.20 & 88.20 & 89.20 & 90.20 & 91.20 & 92.20 & 93.20 & 94.20 \\
\hline & Gas-water ratio $=1.2$ & 85.60 & 86.66 & 87.73 & 88.79 & 89.85 & 90.91 & 91.98 & 93.04 & 94.10 \\
\hline
\end{tabular}


As shown in Tables 1 3, the reflux ratio within the cooling tower is positively correlated with the water temperature, drybulb temperature and relative humidity at the outlet of the cooling tower, but negatively with the heat exchange amount of the tower, under different atmospheric dry-bulb temperatures, atmospheric relative humidities and gas-water ratios. It can be seen that the reflux of water vapour has a significant impact on the cooling performance of the cooling tower, and the impact is positively correlated to the reflux ratio.

\section{CONCLUSIONS}

This paper probes into the thermodynamic performance and heat transfer properties of the CACS in ancient pagodas, establishes a thermodynamic model of the cooling tower in the principle of differential calculation, and verifies the rationality of the proposed model through field test. On this basis, the author further discussed the impacts of drifting and reflux effect on the working performance of the cooling tower. The research conclusions are as follows

(1) Without considering the drifting effect, there is only a slight error between the measured inlet air enthalpy, inlet air temperature and inlet air relative humidity and the values simulated by the proposed model. In actual operation, the drifting of water vapour away from the cooling tower carries away some heat, leading to reduced temperature and increased relative humidity at the air inlet

(2) The reflux ratio within the cooling tower is positively correlated with the water temperature, dry-bulb temperature and relative humidity at the outlet of the cooling tower, but negatively with the heat exchange amount of the tower, under different atmospheric dry-bulb temperatures, atmospheric relative humidities and gas-water ratios. The reflux of water vapour has a significant impact on the cooling performance of the cooling tower, and the impact is positively correlated to the reflux ratio.

\section{REFERENCES}

[1] Jaishi B, Ren WX, Zong ZH, Maskey PN. (2003). Dynamic and seismic performance of old multi-tiered temples in nepal. Engineering Structures 25(14): 18271839. http://dx.doi.org/10.1016/j.engstruct.2003.08.006

[2] Gentile C, Saisi A, Cabboi A. (2015). Structural identification of a masonry tower based on operational modal analysis. International Journal of Architectural Heritage $9(2)$ : 98-110 http://dx.doi.org/10.1080/15583058.2014.951792

[3] Gao DF, Li PF, Wang L. (2012). Study on the structural and aseismatical performance of multi-storey ancient Chinese timber structure shangyou tower of palace style. Advanced Materials Research 535-537. http://dx.doi.org/20122016.10.4028/www.scientific.net/amr.535-537.2012

[4] Bassoli E, Forghieri M, Vincenzi L, Bovo M, Mazzotti C. (2017). Structural health monitoring of a historical masonry bell tower using operational modal analysis. Key Engineering Materials 747: 440-447. http://dx.doi.org/10.4028/www.scientific.net/KEM.747. 440

[5] Bartoli G., Betti M, Vignoli A. (2016). A numerical study on seismic risk assessment of historic masonry towers: A case study in san gimignano. Bulletin of Earthquake Engineering 14(6): 1475-1518. http://dx.doi.org/10.1007/s10518-016-9892-9

[6] Ferraioli M, Miccoli L, Abruzzese D. (2018). Dynamic characterisation of a historic bell-tower using a sensitivity-based technique for model tuning. Journal of Civil Structural Health Monitoring 8(3): 1-17. http://dx.doi.org/10.4028/www.scientific.net/kem.628.5 5

[7] Ditommaso R, Mucciarelli M, Parolai S, Picozzi M. (2012). Monitoring the structural dynamic response of a masonry tower: comparing classical and time-frequency analyses. Bulletin of Earthquake Engineering 10(4). http://dx.doi.org/1221-1235. 10.1007/s10518-012-9347$\mathrm{x}$

[8] Qu TJ, Wang YP, Wang XY. (2013). Experimental study for seismic performance of confined masonry structure. Applied Mechanics \& Materials 353-356: 1826-1831. http://dx.doi.org/10.4028/www.scientific.net/amm.353356.1826

[9] Zhang Q, Jiao Y, Cao M, Jin L. (2017). Simulation analysis on summer conditions of ancient architecture of tower buildings based on cfd. Energy Procedia 143: 313319. http://dx.doi.org/10.1016/j.egypro.2017.12.690

[10] Al-Waked R, Behnia M. (2006). Cfd simulation of wet cooling towers. Applied Thermal Engineering 26(4): 382-395.

http://dx.doi.org/10.1016/j.applthermaleng.2005.06.018

[11] Lin H, Li XH, Cheng PS, Xu BG. (2014). Study on chilled energy storage of air-conditioning system with energy saving. Energy \& Buildings 79(4): 41-46. http://dx.doi.org/10.1016/j.enbuild.2014.04.047

[12] Sayyadi H, Nejatolahi M. (2011). Thermodynamic and thermoeconomic optimization of a cooling towerassisted ground source heat pump. Geothermics 40(3): 221-232. http://dx.doi.org/10.1016/j.geothermics.2011.06.003

[13] Papaefthimiou VD, Zannis TC, Rogdakis ED. (2010). Thermodynamic study of wet cooling tower performance. International Journal of Energy Research 30(6): 411-426. http://dx.doi.org/10.1002/er.1158

[14] Mansour MK, Hassab MA. (2014). Innovative correlation for calculating thermal performance of counterflow wet-cooling tower. Energy 74(5): 855-862. http://dx.doi.org/10.1016/j.energy.2014.07.059

[15] Chabane F, Sekseff E. (2018). Solar air collectors with doubles glazed by different distances in support of mass flow. Instrumentation, Mesure, Métrologie 17(1): 37-53. http://dx.doi.org/10.3166/I2M.17.37-53

[16] Al-Waked R. (2010). Crosswinds effect on the performance of natural draft wet cooling towers. International Journal of Thermal Sciences 49(1): 218224.

http://dx.doi.org/10.1016/j.ijthermalsci.2009.07.012

[17] Fisenko SP, Brin AA. (2007). Simulation of a cross-flow cooling tower performance. International Journal of Heat \& Mass Transfer 50(15): 3216-3223. http://dx.doi.org/10.1016/j.ijheatmasstransfer.2006.05.0 28

[18] Söylemez MS. (2004). On the optimum performance of forced draft counter flow cooling towers. Energy Conversion \& Management 45(15): 2335-2341. http://dx.doi.org/10.1016/j.enconman.2003.11.023

[19] Kloppers JC, Kröger DG. (2005). The lewis factor and its 
influence on the performance prediction of wet-cooling towers. International Journal of Thermal Sciences 44(9): 879-884.

http://dx.doi.org/10.1016/j.ijthermalsci.2005.03.006

[20] Kie PL, Theng LB. (2008). Intelligent control of heating, ventilating and air conditioning systems. Lecture Notes in Computer Science 5507: 927-934.

[21] Gao M, Sun FZ, Wang K, Shi YT, Zhao YB. (2008). Experimental research of heat transfer performance on natural draft counter flow wet cooling tower under crosswind conditions. International Journal of Thermal $\begin{array}{lll}\text { Sciences } & 47(7) \text { : } & \text { 935-941. }\end{array}$ http://dx.doi.org/10.1016/j.ijthermalsci.2007.07.010

[22] Smrekar J, Oman J, Širok B. (2006). Improving the efficiency of natural draft cooling towers. Energy
Conversion \& Management 47(9-10): 1086-1100. http://dx.doi.org/10.1016/j.enconman.2005.07.012

[23] Alavi SR, Rahmati M. (2016). Experimental investigation on thermal performance of natural draft wet cooling towers employing an innovative wind-creator setup. Energy Conversion \& Management 122: 504-514. http://dx.doi.org/10.1016/j.enconman.2016.06.016

[24] Qi X, Liu Z, Li D. (2007). Thermodynamic calculation model of hollow cooling tower. Industrial Water Treatment 27(8): 61-65.

[25] Zhang Q, Wu J, Zhang G, Zhou J, Guo Y, Shen W. (2012). Calculations on performance characteristics of counterflow reversibly used cooling towers. International Journal of Refrigeration 35(2): 424-433. http://doi.org/10.1016/j.ijrefrig.2011.10.016 